INTERNATIONAL JOURNAL OF

SYSTEMATIC BACTERIOLOGY

Vol. 16, No. 4

October 1966

pp. $377-382$

\title{
RECOMMENDATIONS FOR REVISION OF THE TAXONOMIC TREATMENT OF STALKED BACTERIA
}

Jeanne S. Poindexter ${ }^{1}$ and R.F. Lewis 2

SUMMARY. During the past few years, observations on stalked bacteria have been reported that permit a meaningful reevaluation of their taxonomic treatment. We recommend here that two families of stalked bacteria be recognized: Caulobacteraceae, to comprise bacteria whose stalk is an integral part of the cell, and Gallionellaceae, to comprise bacteria whose stalk is a secreted structure. Two genera should be included in Caulobacteraceae, viz., Caulobacter Henrici and Johnson and Asticcacaulis Poindexter. A single genus, Gallionella Ehrenberg, should be included in Gallionellaceae. The genera Siderophacus and Nevskia should not be included in either family, since cultivated cells of these genera have not yet been studied; their affinity to Gallionellaceae is acknowledged.

In the most recent edition of Bergey's Manual of Determinative Bacteriology (1957), all stalked bacteria are classified in the family Caulobacteraceae Henrici and Johnson. We propose changes in this classification to accommodate recent experimental observations on physiological and cytological characteristics of stalked bacteria.

1. The family should be classified as two taxa, and the family Gallionellaceae Henrici and Johns on should be reinstated. The family Caulobacteraceae should comprise bacteria possessing stalks which are an integral part of the cell (Poindexter and Cohen-Bazire, 1964; Pate and Ordal, 1965). All such bacteria that have been cultivated have been shown to be chemoheterotrophic (Houwink, 1951, 1955; Bowers et al. , 1954; Gromov, 1964; Poindexter, 1964).

Department of Bacteriology, Indiana University, Bloomington, Indiana.

2 Cincinnati Water Research Laboratory, Federal Water Pollution Control Administration, Cincinnati, Ohio. 
The family Gallionellaceae should comprise bacteria possessing stalks composed of secreted mucilaginous material (van Iterson, 1958; Vatter and Wolfe, 1956). Although unquestionably pure cultures have not yet been obtained, the enrichment methods which have proved successful as means of obtaining growth of such bacteria in the laboratory suggest that they are chemoautotrophic (Henrici and Johnson, 1935b; Kucera and Wolfe, 1957), or at least facultatively chemoautotrophic (van Iterson, 1958).

The two known groups of stalked bacteria should be recognized as sufficiently distinct to justify classification in separate families. Since motility in both groups is associated with the presence of a polar or subpolar flagellum or pair of flagella (Houwink and van Iterson, 1959; van Iterson, 1958), and since none of the stalked bacteria are photosynthetic, both families should be retained within the suborder Pseudomonadineae.

2. As recommended earlier (Poindexter, 1964), the family Caulobacteraceae should comprise the two genera Caulobacter Henrici and Johnson, as redefined by Poindexter (1964), and Asticcacaulis Poindexter (1964). The principal distinction between these two genera is the presence of adhesive material at the distal end of the stalk of Caulobacter, in contrast to the absence of such material from the Asticcacaulis stalk. Various physiological characteristics are correlated with this structural difference, and studies on the bacteriophages of Caulobacter and Asticcacaulis have revealed that each of the viruses isolated is capable of infecting members of only one of the genera (Schmidt and Stanier, 1965).

On the basis of the observations of Poindexter and of Schmidt and Stanier, we propose that in a revised classification of Caulobacteraceae the existence of the several species of Caulobacter and of the genus Asticcacaulis be recognized. The organization proposed for the family is presented in section 5 of this paper.

Poindexter (1964) stated that the strain of Caulobacter isolated by Bowers et al. (1954) and identified as $\underline{\text { C. vibrio- }}$ ides Henrici and Johnson was the neotype strain. However, this strain has not been recognized as such, and we here propose that the "typical strain" CB51 of Poindexter be recognized as the neotype strain of $\underline{C}$. vibrioides. The type strains of several of the species and subspecies named by 
Poindexter have been deposited with the American Type Culture Collection; their accession numbers are given in section 5 of this paper.

3. The description of Gallionellaceae should be emended as follows:

Family Gallionellaceae Henrici and Johnson 1935

Type genus Gallionella Ehrenberg 1836

Straight or curved rod-shaped bacteria, nonfilamentous, which secrete stalks from one side of the cell. Stalks may be branched or unbranched, straight, twisted, or slightly curved; in one genus (Gallionella) the stalk may contain ferric hydroxide. One or two polar flagella may be present on the cell, although stalked cells are characteristically nonmotile. Multiply by transverse fission. Found in fresh and salt water, apparently free-living.

The type genus should be the only genus included in this family. The type species is Gallionella ferruginea Ehrenberg 1836, as further described by Cholodny (1924) and Vatter and Wolfe (1957). The designations of other species of Gallionella have been based on characteristics such as variations in size or shape of the cells and degree of branching or twisting of the stalks. These distinctions are based solely on observations on natural materials; consequently, they are not dependable as taxonomic criteria. Such observations can neither take into account the effects on morphology of variations in environmental conditions in which the cells are growing, nor determine the age and viability of the cells examined. Especially in the case of organisms such as Gallionella, the examination of materials from environments containing different amounts of dissolved iron may be misleading; additional misconceptions may derive from the examination of only fragments of microcolonies. For these reasons, we feel that recognition of Gallionella species other than G. ferruginea is not justified. Recognition of additional species must await cultivation of slime-stalked bacteria in the laboratory and the demonstration that significant differences in nutrition, physiology, and morphology exist.

4. The genera Siderophacus and Nevskia should be excluded from the families of stalked bacteria. This exclusion is recommended because of the absence of studies on laboratory-cultivated cells. These genera should be in an appen- 
dix of "Bacteria that have been named, but not cultivated" wherein their similarity to Gallionellaceae should be acknowledged. A more refined classification of these slimestalked bacteria should await determination of cultural characteristics, with particular attention being given to an evaluation of the role of iron oxidation in metabolism and to the effects of the environment on morphological characteristics.

5. The following classification is recommended as a reorganization of the genera that comprise stalked bacteria;

1. Family Caulobacteraceae (Caulobacteriaceae [sic]) Henrici and Johnson 1935

Type genus: Caulobactet Henrici and Johnson 1935 emend. Poindexter 1964

A. Genus Caulobacter

Type species: C. vibrioides Henrici and Johns on 1935 emend. Bowers et al. 1954 emend. Poindexter 1964

1. C. vibrioides; neotype strain CB51 (Poindexter, 1964)

C. vibrioides limonus subsp. Poindexter; type strain $\mathrm{CB} 16$

2. C. crescentus Poindexter; type strain $\mathrm{CB} 2$, ATCC 15252

3. C. henricii Poindexter; type strain CB4, ATCC 15253

C. henricii aurantiacus subsp. Poindexter; type strain CB-R, ATCC 15266

4. C. intermedius Poindexter; type strain CB63, ATCC 15262

5. C. subvibrioides Poindexter; type strain CB81, ATCC 15264

C. subvibrioides albus subsp. Poindexter; type strain CB88, ATCC 15265

6. C. fusiformis Poindexter; type strain CB27, ATCC 15257

7. C. leidyi Poindexter; type strain CB37, ATCC 15260

8. C. bacteroides Poindexter; type strain CB7, ATCC 15254

9. C. halobacteroides Poindexter; type strain $\mathrm{CMl3}$, ATCC 15269 
10. C. maris Poindexter; type strain CMll, ATCC 15268

11. C. variabilis Poindexter; type strain CB17, ATCC 15255

B. Genus Asticcacaulis Poindexter 1964

Type species: A. excentricus Poindexter 1964

1. A. excentricus Poindexter; type strain AC48

II. Family Gallionellaceae Henrici and Johnson 1935

Type genus: Gallionella (Gaillonella [sic]) Ehrenberg 1836

A. Genus Gallionella Ehrenberg

1. G. ferruginea Ehrenberg 1836

These recommendations are intended as a guide for the editors of further editions of Bergey's Manual of Determinative Bacteriology.

\section{REFERENCES}

Bowers, L.E., R.H. Weaver, E. A. Grula, and O.F.

Edwards. 1954. Studies on a strain of Caulobacter from water. I. Isolation and identification as Caulobacter vibrioides Henrici and Johnson with emended description. Jour. Bact. 68:194-200.

Breed, R.S., E.G. D. Murray, and N.R. Smith. 1957.

Bergey's Manual of Determinative Bacteriology, 7 th ed. The Williams and Wilkins Co., Baltimore.

Cholodny, G.N. 1924. Zur Morphologie der Eisenbakterien Gallionella und Spirophyllum. Berichte d. deutsch. Bot. Gesellsch. 42:35-44.

Gromov, B. V. 1964 . Bacteria of the Caulobacter genus accompanying algae in cultures. Microbiology 33:398405.

Henrici, A. T. and D. Johnson. 1935a. Stalked bacteria. a new order of Schizomycetes. (Abst.) Jour. Bact. 29:3-4. and $1935 \mathrm{~b}$. Studies of freshwater bacteria. II. Stalked bacteria, a new order of schizomycetes. Jour. Bact. 30:61-93.

Houwink, A.L. T951. Caulobacter versus Bacillus spec. div. Nature 168:654. 
- 1955. Caulobacter. Its morphogenesis, taxonomy and parasitism. Antonie van Leeuwenhoek Jour. Microbiol. Serol. 21:49-64. and W. van Iterson. 1950. Electron microscopical observations on bacterial cytology. II. A study on flagellation. Biochim. Biophys. Acta $\underline{5}: 10-44$.

Kucera, S., and R.S. Wolfe. 1957. A selective enrichment method for Gallionella ferruginea. Jour. Bact. 74:344349.

Pate, J. L. and E. J. Ordal. 1965. The fine structure of two unusual stalked bacteria. Jour. Cell Biol. 27:133150.

Poindexter, J.S. 1964. Biological properties and classification of the Caulobacter group. Bact. Rev. 28:231-295. and G. Cohen-Bazire. 1964. The fine structure of stalked bacteria belonging to the family Caulobacteraceae. Jour. Cell Biol. 23:587-607.

Schmidt, J.M. and R.Y. Stanier. 1965. Isolation and characterization of bacteriophages active against stalked bacteria. Jour. Gen. Microbiol. 39:95-107.

van Iterson, W. 1958. Gallionella ferruginea in a different light. (Ph. D. Thesis, University of Amsterdam) N.V. Noord Hollandsche Uitgevers Maatschappij, Amsterdam; $185 \mathrm{pp}$.

Vatter, A.E. and R.S. Wolfe. 1956. Electron microscopy

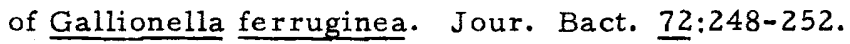

